\title{
An Observation of Arboreal Behavior in a Spring Peeper (Pseudacris crucifer)
}

Sean M. Hartzell ${ }^{1}$ and Robyn E. Woodley ${ }^{2}$

${ }^{1}$ Department of Biological and Allied Health Sciences, Bloomsburg University of Pennsylvania, Bloomsburg, Pennsylvania 17815, USA (smh14844@huskies.bloomu.edu)

${ }^{2}$ Ambrosia Photography, Shippensburg, Pennsylvania 17257, USA

Photograph by the second author.

S pring Peepers (Pseudacris crucifer) are small frogs that inhabit deciduous woodlands throughout the eastern United States and southeastern Canada (Dodd 2013). Outside of the breeding season, $P$. crucifer is uncommonly encountered, but when observed is typically within or among terrestrial debris such as leaf litter, stumps, downed logs, and other woody debris (Carr 1940; Hulse et al. 2001; Dodd 2013). On 10 June 2014 at approximately 1500 h, we observed an adult $P$. crucifer ascend a large deciduous tree (Fig. 1) in Caledonia State Park, Franklin Co., Pennsylvania, USA $\left(39.909453^{\circ} \mathrm{N}, 77.473188^{\circ} \mathrm{W}\right.$; WGS 84). We initially noted the $P$. crucifer on the base of a large tree approximately $15 \mathrm{~cm}$ above the ground along a hiking trail in mixed-deciduous forest. We observed and photographed the frog for approximately $5 \mathrm{~min}$, during which it climbed from its initial position on the base of the tree to a height of approximately $3 \mathrm{~m}$ above the ground.

When foraging, Pseudacris crucifer will often ascend herbaceous vegetation and low-lying woody shrubs (McAlister 1963; Hulse et al. 2001; Dodd 2013). However, in their synthesis of the natural history of the herpetofauna of Pennsylvania and the northeastern United States, Hulse et al. (2001) remarked that this species appears to avoid climbing trees. Thus, our observation struck us as unusual and prompted us to review the literature regarding arboreal behavior in P. crucifer. Carr (1940) reported finding P. crucifer estivating under bark and in knotholes in Florida, suggesting arboreal behavior (Dodd 2013). Additionally, Ashton and Ashton (1988) and Dodd $(2004,2013)$ noted P. crucifer in trees or calling from forest canopies in the late summer or early fall in the southeastern United States.

So, our observation of Pseudacris crucifer climbing a tree does not appear to be particularly unusual, although it is the first published report of arboreal behavior in P. crucifer from Pennsylvania. Numerous authors (e.g., McAlister 1963; Conant and Collins 1998; Hulse et al. 2001; Dodd
2013) have noted that $P$. crucifer is cryptic and infrequently observed outside of the breeding season. Consequently, in hindsight, Hulse et al. (2001) might have stated that arboreality in $P$. crucifer appears to be rare due to the paucity of observations of this species outside of the breeding season.

\section{Acknowledgements}

We thank two anonymous reviewers for comments on this note.

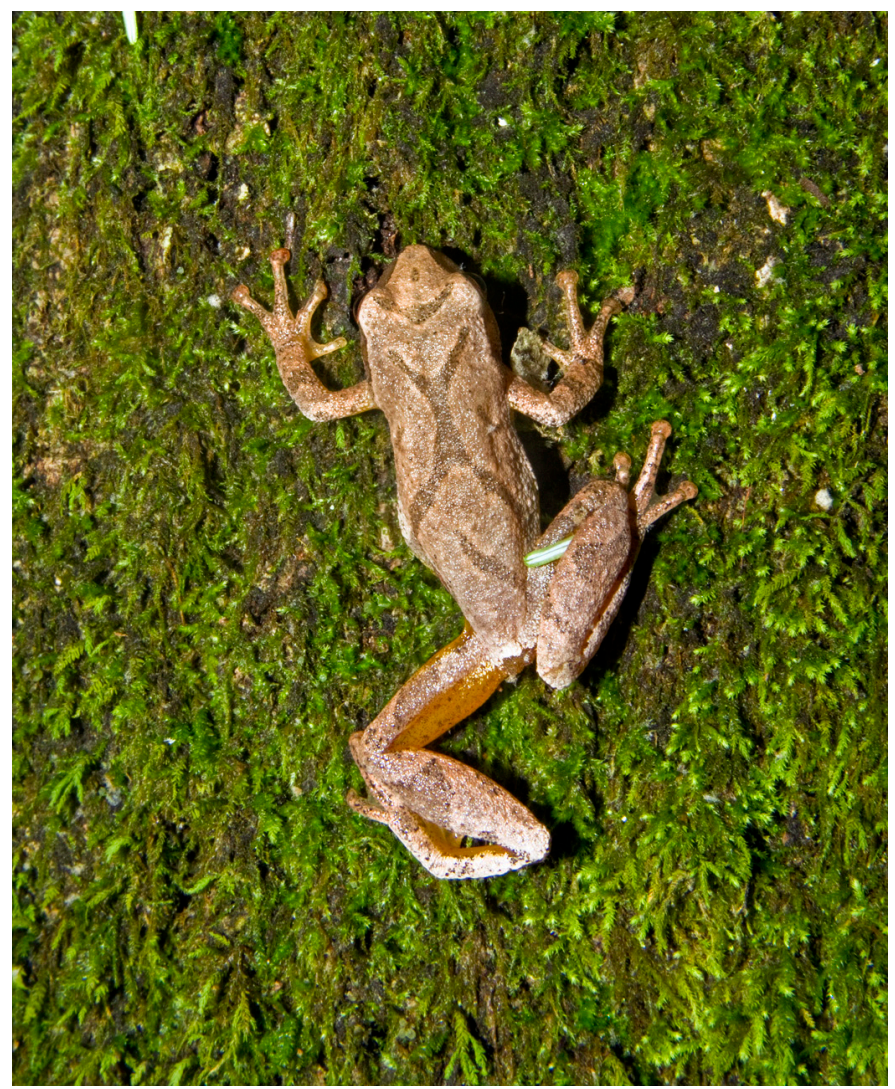

Fig. 1. Spring Peeper (Pseudacris crucifer) ascending a tree in Caledonia State Park, Franklin Co., Pennsylvania. 


\section{Literature Cited}

Ashton, R.E., Jr. and P.S. Ashton. 1988. Handbook of Reptiles and Amphibians of Florida: Part Three, The Amphibians. Windward Publishing Company, Miami, Florida.

Carr, A.F. Jr. 1940. A contribution to the herpetology of Florida. University of Florida Publication, Biological Science Series 3: 1-118.

Conant, R. and J.T. Collins. 1998. A Field Guide to Reptiles and Amphibians of Eastern and Central North America. (3rd ed., expanded). Houghton Mifflin, New York.
Dodd, C.K., Jr. 2004. The Amphibians of Great Smokey Mountains National Park. University of Tennessee Press, Knoxville, Tennessee.

Dodd, C.K., Jr. 2013. Frogs of the United States and Canada. Johns Hopkins University Press, Baltimore, Maryland.

Hulse, A.C., C.J. McCoy, and E.J. Censky. 2001. Amphibians and Reptiles of Pennsylvania and the Northeast. Cornell University Press, Ithaca, New York.

McAlister, W.H. 1963. A post-breeding concentration of the Spring Peeper. Herpetologica 19: 293. 